\title{
Factors Affecting SOC and NPK in the Rangeland, Forest and Agriculture; Case Study Halashi Catchment, Kermanshah, Iran
}

\author{
Shohreh Abdolmohamadi ${ }^{1}$, Alireza Ildoromi' ${ }^{1}$ Mosayeb Heshmati ${ }^{2 *}$ \\ ${ }^{1}$ Faculty of Natural Resources, Malayer University, Malayer, Iran \\ ${ }^{2}$ Soil Conservation and Watershed Management Department, Kermanshah Agricultural and Natural Resources Research and \\ Education Center, Agricultural Research, Education and Extension Organization (AREEO), Tehran, Iran \\ Email: *heshmati46@gmail.com
}

How to cite this paper: Abdolmohamadi, S., Ildoromi, A. and Heshmati, M. (2017) Factors Affecting SOC and NPK in the Rangeland, Forest and Agriculture; Case Study Halashi Catchment, Kermanshah, Iran. Journal of Geoscience and Environment Protection, 5, 18-30.

https://doi.org/10.4236/gep.2017.513002

Received: November 12, 2017

Accepted: December 25, 2017

Published: December 28, 2017

Copyright $\odot 2017$ by authors and Scientific Research Publishing Inc. This work is licensed under the Creative Commons Attribution International License (CC BY 4.0).

http://creativecommons.org/licenses/by/4.0/

(c) (i) Open Access

\begin{abstract}
Land use change causes soil disturbance and thereby considerable soil nutrients depletion and environmental impacts. This research was conducted in Halashi catchment, Kermanshah, Iran to compare the variation of soil NPK and SOC in Agricultural Lands (AL), Rangelands (RL) and Forest lands (FL). The coverage of ground surface including plant crown, stone and litter was estimated in field by using quadrate plot $\left(1 \mathrm{~m}^{2}\right)$. Soil sampling and the analysis were carried out for each land use during April and May, 2015. Inter-rill, rill, gully and landslide were found as the dominant erosion features. The ANOVA analysis explored no considerable differences for soil texture, $\mathrm{pH}$ and Electrical Conductivity (EC). High clay and silt content induced clayey and silty soil that means Soil Organic Carbon (SOC) level in the AL, RL and FL were 1.14\%, $1.45 \%$ and $2.13 \%$, respectively, showing significant $(\mathrm{p} \leq 0.05)$ different from each other among them. The respective values of total $\mathrm{N}$ in the AL, RL and FL were 0.14 , 0.14 and $0.18 \mathrm{mg} / \mathrm{kg}$, indicating significant decrease in the AL and RL. The respective mean avails $\mathrm{P}$ and exch. $\mathrm{K}$ in the $\mathrm{AL}, \mathrm{RL}$ and FL were 15.72, 11.44, $11.38 ; 342.5,375.0$ and $374.5 \mathrm{mg} / \mathrm{kg}$. Crop residues burning and tillage practicing cause depletion of SOC and NPK in AL, while as compared with FL, lower vegetation canopy and litter in the RL promotes soil nutrients and SOC lost due to overgrazing and converting to rain-fed lands. As a conclusion, rangeland was the intermediate site in terms of soil nutrient and SOC stock in the Halashi.
\end{abstract}

\section{Keywords}

Halashi Catchment, Soil Nutrients, Organic Carbon, Tillage Practice 


\section{Introduction}

The change of Land use, especially converting range and forest to rain-fed areas causes soil disturbance and thereby considerable environmental impacts. It is a major worldwide environmental problem affecting climate, soil nutrient depletion, vegetation coverage, economy and human welfare due to decline in soil quality and health caused by misuse of agriculture and rangeland [1] [2]. However, off-site impacts of losing soil nutrients through land use have been regarded as one of the most global warming and aquatic pollution (eutrophication) phenomena [3].

In Iran, the size, abundance and biodiversity of rangeland and forest have been destroyed by human activities such as improper grazing, fragmentation and converting to agricultural land depleting $50 \%$ of SOC and $15 \%$ soil N [4] [5].

Gully thresholds were reduced significantly in the rain-fed area in comparison with adjacent rangeland [6]. Reduction in erosion thresholds was related to native vegetation cover and thereby soil organic carbon contents, particularly grasses. The flexible stems and strong root systems of grasses reduce overland flow velocity and capture loaded sediment particles [7]. Converting rangelands and forest to marginal areas such as rain-fed lands contribute to negative changes in critical soil characteristics. It is reported as the considerable environmental challenges in Zagros, Iran. Thus, converting rangeland and forest in the Zagros area attribute to significant depletion of soil nutrients and organic carbon [8] [9] [10]. It is estimated that there were 9.4 million grazing animals in the rangelands and forests in the upper Karkheh Basin, which is a part of the Zagros regions [5].

In these areas, overgrazing is carried out by rural inhabitants and nomads that exist above the carrying rangeland capacity declining their dry forage and condition. In addition, Zagros forests are being accelerated fragmentation in the vicinity of the agricultural areas due to logging and cultivation practices. Fragmented forests cause rapid change in land use leading to larger perimeter/forest path ratio resulting in soil quality degradation [11].

However, off-site impacts of improper agricultural activities, overgrazing and deforestation are related to NPK depletion and SOC flux. For instance, 50\% of N and $30 \%$ of $\mathrm{P}$ removed from agricultural areas end up in rivers [3]. Most cultivated soils have lost between $30 \%$ and $50 \%$ of their original SOC pool, whereas severely eroded soils may have lost 70 - 80 percent [12]. In contrast, plant patches of rangeland and forest play an important role in reducing erosive processes, enhancing water infiltration and promoting nutrient cycling [13].

Improper tillage practices strongly accelerate soil erosion processes by destroying soil organic matter (SOM) and soil structure [14] [15]. The improper utility of rangeland cause soil erosion mainly gullies erosion control and thereby nutrients and SOC stocks [16]. Different land use affecting SOC fluxes in the rangeland, orchard and rain-fed in China revealed that SOC depletion in rain-fed site was lower than that other sites [17]. The steep slope agricultural landscape cause consider- 
able NPK depletion and SOC emotion during rainfall event [18].

This research was carried out during 2015-16 in Halashi catchment, Kermanshah, Iran to compare the variation of soil NPK and SOC in different land uses including rangeland, forest and agricultural areas.

\section{Materials and Methods}

\subsection{The Study Area}

This study was conducted at the Halashi catchment, located about $30 \mathrm{~km}$ southeast of Kermanshah, Iran (Figure 1) where is a part of Zagros mountain chains, at the west of Iran. The study area (7357 ha) included forest (927 ha), rangeland (2229 ha) and agriculture (4200 ha). It lies between $34^{\circ} 00^{\prime} 38^{\prime \prime} \mathrm{N}$ to $34^{\circ} 09^{\prime} 20^{\prime \prime} \mathrm{N}$ and $47^{\circ} 04^{\prime} 20^{\prime \prime} \mathrm{E}$ to $47^{\circ} 21^{\prime} 15^{\prime \prime} \mathrm{E}$ (UTM 1984; zone $38 \mathrm{~N}$ ). The minimum and maximum elevations above sea level are 1440 and $2720 \mathrm{~m}$, respectively that means annual precipitation and temperature are $470 \mathrm{~mm}$ and $18^{\circ} \mathrm{C}$, respectively indicating a semi-arid region.

Geological layers contain limestone, sandstone, shale and marls deposits of Cretaceous, Pleistocene and Miocene forming a soil with moderate to good conditions in terms of CEC, $\mathrm{pH}$, nutrients and soil depth for vegetation and agricultural activities. However, this catchment is currently suffering from anthropogenic environment degradation mainly deforestation, heavy grazing and improper agricultural activities representing main land use change in the Zagros regions of Iran. About $37 \%$ of the study area is occupied by rangeland and forest,

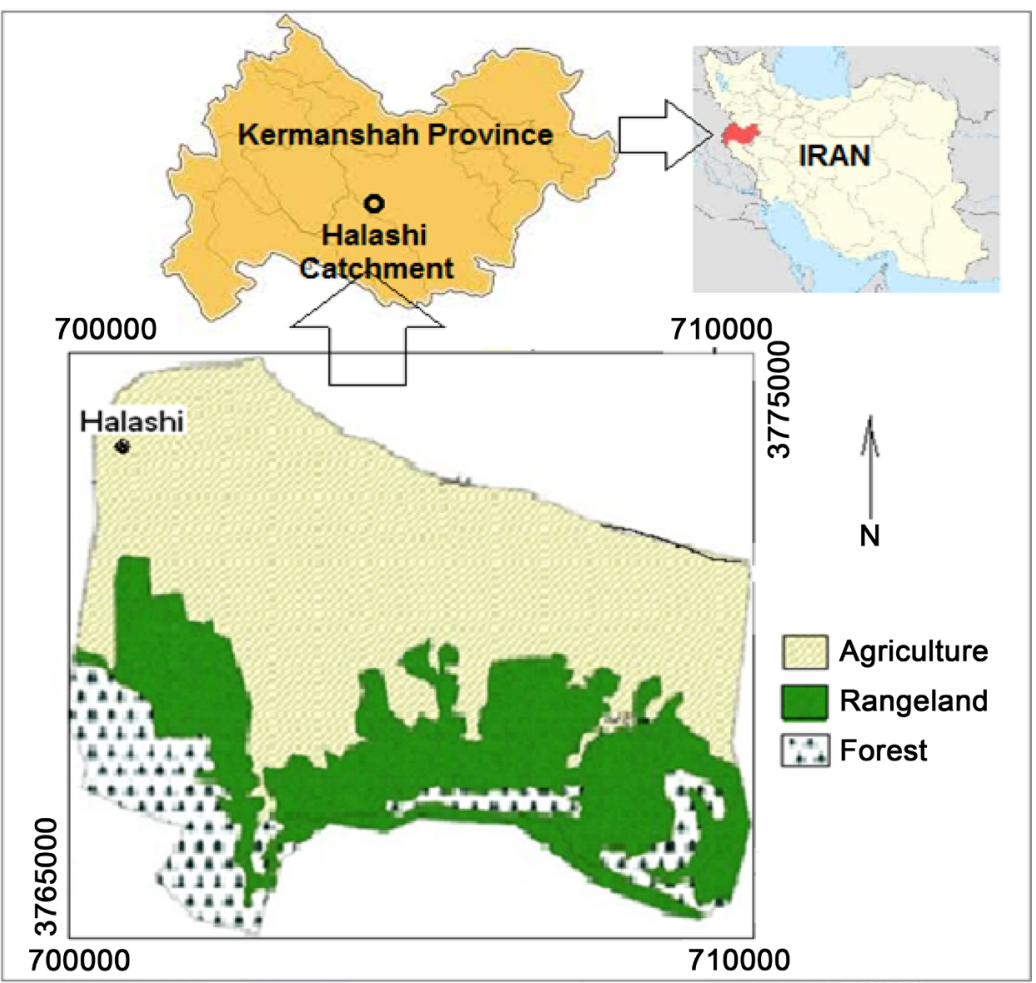

Figure 1. Location of the Halashi catchment in Kermanshah and Iran. 
which are more sensitive to soil erosion due to topography and geological properties.

\subsection{Preparing the Maps}

The maps of land use, geology, erosion form and vegetation for this study were prepared by using satellite images and topographic maps $(1: 50,000)$. The geology map was prepared based on geology quadrangle map of Kermanshah (on a scale of 1:100,000), using data obtained from the Geological Survey of Iran (GSI) [19].

The map of forest and rangeland was prepared based on physiognomy method and nominated by two to three dominant plant species. Finally the border of each map was checked in the field. Vegetation type of rangeland was nominated by three dominants plant species based on their ground surface coverage (\%). The above ground covers refer to the area covered by the vertical projection of the plant crown, stone and litter onto the soil surface. There were estimated on field using a quadrate plot $\left(1 \mathrm{~m}^{2}\right)$. The forest is dominated by oak (Quercus persica).

\subsection{Soil Sampling and Analyses}

Thirty eight soil samples were collected from $0-20 \mathrm{~cm}$ depth within each land use followed by stratified random soil sampling and their coordinates were determined by global positioning system (GPS). The dried soil samples were sieved through $2 \mathrm{~mm}$ mesh sieve. Soil physicochemical characteristics were determined in the laboratory. The particle size distribution and soil texture were determined by hydrometric method [20]. The $\mathrm{pH}$ of the saturated soil paste was measured by a pH meter. Soil organic carbon was determined by the Walkley and Black method [21]. Total nitrogen was determined by the Kjeldahl method [22]. Available phosphorus was measured by the method of Olsen [23]. Exchangeable potassium was extracted by $\mathrm{NH} 4 \mathrm{OAc}$ buffered at $\mathrm{pH} 7.0$ and $\mathrm{K}$ in the solution was determined by flame photometer [24]. The sample was centrifuged and extracted solution run by atomic absorption spectrophotometer (Perkin-ELMER).

\subsection{Statistical Analyses}

The data were statistically analyzed using SAS version 6.12 for variance of each soil variable including one way ANOVA (General Linear Models (GLM) procedure and Student Newman Keuls (SNK) test due to unequaled samples size) at 0.05 probability level.

\section{Results and Discussion}

\subsection{Geology, Topography and Erosion Forms}

The most parts of the studied area are occupied by fine grained materials of marl deposits including younger terraces, older terraces, Kashkan (marl) and Shabazan formations as shown in Figure 2. An outcrop of Kashkan Formation shows the presence of reddish claystone, siltstone and sandstone, inter-layered with conglomerate 


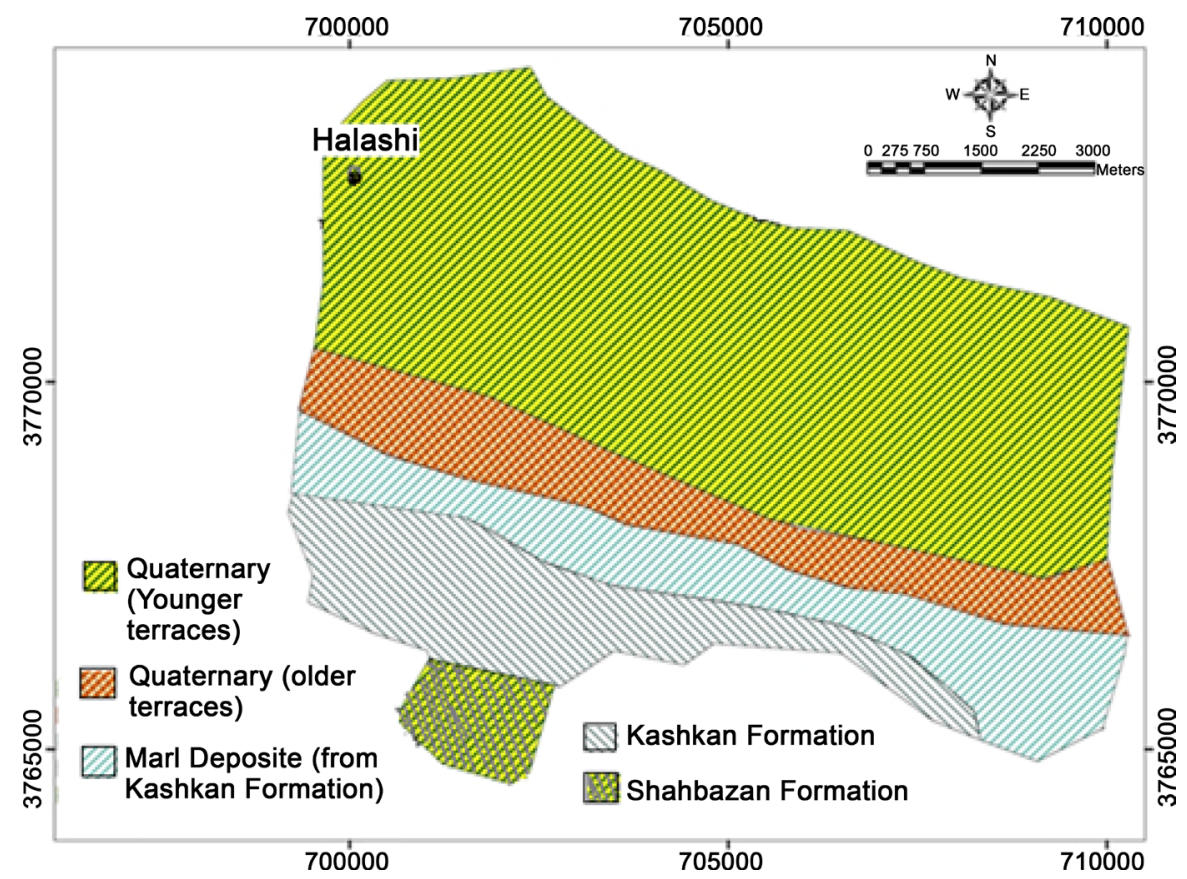

Figure 2. Geological formations in the Halashi catchment.

and limestone. The topographic landscape of Kashkan includes hilly areas which are susceptible to piping and landslide incidence.

Shahbazan includes limestone with high holes and pores on exposed outcrops. The main areas of this catchment are occupied by Quaternary deposits comprising older and younger comprising marl, argillaceous, sand and silt deposits with middle layers of gravel, and limestone which originated from adjacent geological formations in upper parts (mainly Kashkan formation).

Gully and river bank are dominants erosion forms in the agricultural areas. In these areas, gullies occur and develop where geologic structures are susceptible to gully forming due to fine-grained materials such as clay and silt. It is humaninduced by agricultural activities, vegetation clearance and farming practices as well, it can be developed by concentrated runoff that leads to fluvial incision [25] [26].

Inter-rill (sheet erosion) with rill erosion was found as the dominant erosion feature in the rangeland and some parts of rain-fed areas where hillslope is 10\% $20 \%$. Tillage practice and overgrazing contribute to accelerating this erosion. Rill erosion is initiated where overland flow becomes channeled and sheer stress (by overland flows) is more than shear strength of the soils [27], causing severs sedimentation and SOC lost [28].

Land slide in the studied site potentially refers to geological properties, while it occurs mainly through human-induced deforestation. The effective factors on landslide include slope, aspect, topography, climate, lithology, tectonic, vegetation cover, physicochemical and mechanical characteristics of sliding layer and human activities. This is considerable in forest area where Kashkan is dominant geological formation. 
The smectite is a major mineral in both parent material and the soil of Kashkan formation [8]. As such, soil erosion was high especially in the areas with soils containing smectite (with high potential to absorb water) resulting in swellcrack occurrence and damaging the engineering structures in the study area. In the forest, soil erosion, sedimentation, piping, gulling and landslides often take place.

In some areas where marl layers are overlain by limestone, swelling smectite causes sliding of marl layers and shrinks upon dehydration, leading to cracking of clay rich materials [29]. Landslide occurrence is also related to the absorption of water by smectite during the rainy season. It can absorb water and can expand up to $30 \%$ of its original volume [30]. Field observation demonstrated that during the wet season the soil in lands with gully and landslide (where smectite is dominant mineral) absorbs water and expands, increasing cracking and piping which in turn, induce gully erosion and landslide occurrence (Table 1, Figure 3).

Table 1. Geology, topography, erosion forms and dominant improper land use practices in the Halashi catchment affecting soil nutrients and SOC lost.

\begin{tabular}{|c|c|c|c|c|c|c|c|c|}
\hline \multirow{2}{*}{ Land use } & \multicolumn{3}{|c|}{ Geology } & \multicolumn{3}{|c|}{ Topography } & \multirow{2}{*}{ Erosion Form } & \multirow{2}{*}{ Dominants Improper Practices } \\
\hline & Era & Period & Formation & Slope (\%) & Aspect & Altitude (m) & & \\
\hline Agriculture & $\mathrm{Ce}$ & Qt & Qtc & $5-10$ & $\mathrm{P}-\mathrm{N}$ & $1420-1600$ & Sheet-gully-river bank & $\begin{array}{l}\text { Up-down the slope tillage, crop residue } \\
\text { burning }\end{array}$ \\
\hline Rangeland & $\mathrm{Me}$ & $\mathrm{Cr}$ & Ilam & $10-20$ & $\mathrm{~N}$ & $1500-1600$ & Sheet-rill & Overgrazing, converting to rain-fed area lands \\
\hline Forest & $\mathrm{Ce}$ & Ter & $\mathrm{Ka}$ & $10-20$ & $\mathrm{~N}$ & $1600-1900$ & Landslide-piping & $\begin{array}{l}\text { Converting to rain-fed area, illegal grazing, } \\
\text { charcoal extraction, }\end{array}$ \\
\hline
\end{tabular}

$\mathrm{Ce}=$ Cenozoic, $\mathrm{Me}=$ Mesozoic, $\mathrm{Qtc}=$ Quaternary (cultivate area), Ter $=$ Tertiary, Qtf $=$ Quaternary (gravel fan), Ka $=$ Kashkan, $\mathrm{Sh}=\mathrm{Shahbazan}, \mathrm{P}=\mathrm{Plain}$, $\mathrm{N}=$ North.

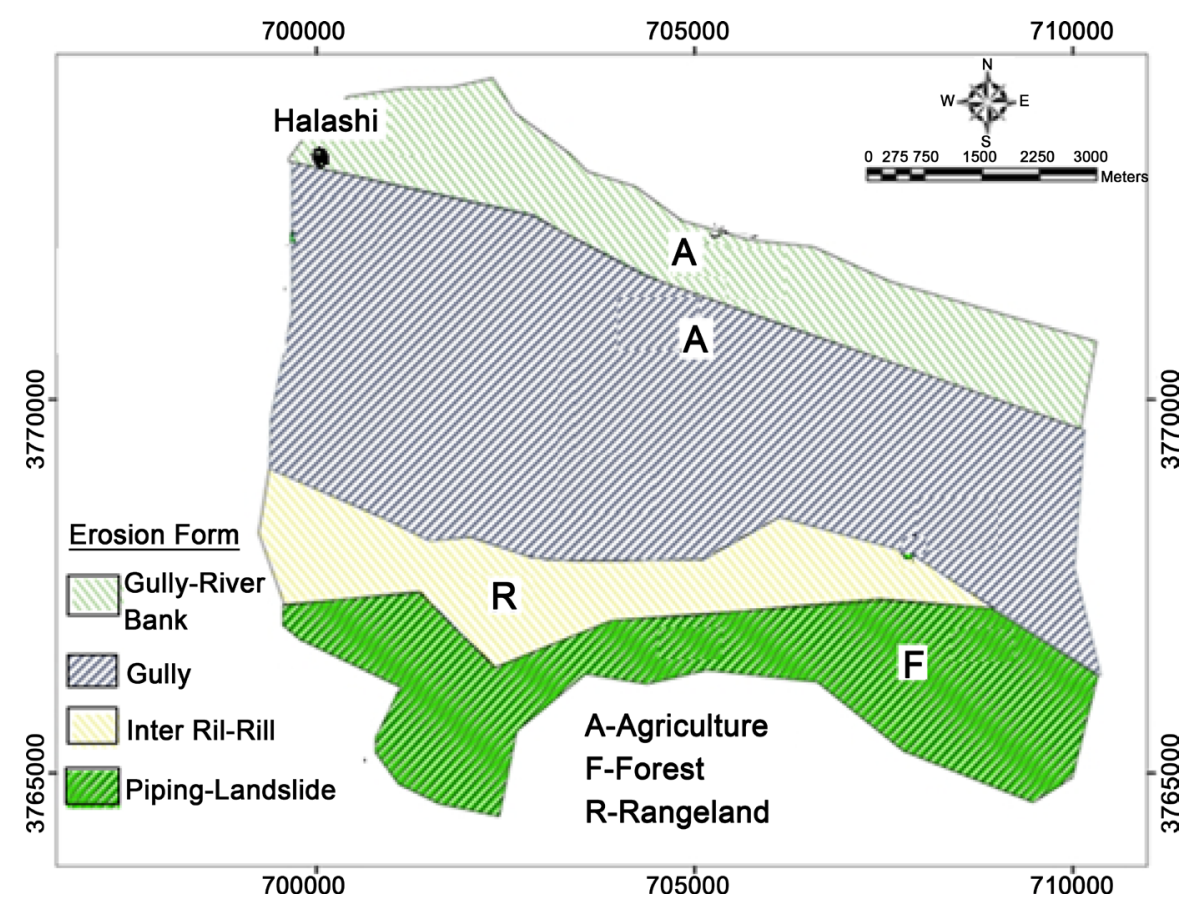

Figure 3. Dominant erosion forms in Halashi catchment. 


\subsection{Ground Cover}

Rangeland of study area includes one vegetation type namely Daphenea. $S p$, $A s$ tragalus. $s p$, and Bromus $s p$. The above ground cover including plant canopy, bare soil, plant litter and stoniness in this type was estimated 41.7, 25.3, 3 and 30\%, respectively. Furthermore, these respective values in understory of forest were 57, $18,9 \%$ and $18 \%$ (Table 2), which in turn, both plant coverage and litter in the forest were more than rangelands.

The inventory of the RL and FL showed that Astragalus sp, Amygdalus sp., Festuca ovina, Quercus persica and Daphnae sp. with annual species are dominant vegetations in the study site. Although the forest is preserved, nomads allow their herd to graze from early spring until Mid-summer sharing deforestation and soil degradation. There is more considerable where forest canopy cover is less than $50 \%[31]$.

\subsection{Soil Texture, $\mathrm{pH}$ and EC}

Descriptive statistical analysis of soil variables and their ANOVA are presented in Table 3 and Table 4. The average amount of sand in the AL, RL and FL are $21.23 \%, 30.1 \%$ and $21.75 \%$, respectively that was significantly higher $(\mathrm{p} \leq 0.05)$ in the RL than those other sites. Mean soil clay in that orders were found $40.21 \%$, $41.63 \%$ and $37.37 \%$ and no significant differences among them. However, the respective levels of soil clay in the AL, RL and FL are $38.03 \%, 31.33 \%$ and $40.52 \%$ revealing lower in the RL. Overall soil in the study area was mainly clayey and silty in nature due to considerable amounts of silt and clay, thereby susceptible to erosion hazards. High clay content would tend to increase water absorption which may promote piping and sliding through increasing dissolve phenomenon. Furthermore, higher slope in FL and RL (more than 15\%) cause transport of clay particles.

The mean soil $\mathrm{pH}$ value of the agriculture, rangeland and forest are 7.72, 7.79 and 7.77, respectively indicating moderate alkalinity. The soils are moderately alkaline with $\mathrm{pH}$ value of 7.4 - 8.4. The $\mathrm{pH}$ of the soils in the study area was not expected to have a significant relationship with the soil degradation (Table 3 and Table 4). The average value of EC was found $0.85,0.66$ and $0.71 \mathrm{dS} / \mathrm{m}$ in the $\mathrm{AL}, \mathrm{RL}$ and FL respectively and no significant difference $(\mathrm{p} \leq 0.05)$ among them showing not effects for soil dispersion potential.

Table 2. Ground cover of rangeland and forest in the Halashi catchment.

\begin{tabular}{cccccc}
\hline & & \multicolumn{3}{c}{ Ground Cover Percentage } \\
\cline { 3 - 6 } Land Use & Vegetation Types & Plant & Bare & Plant & Stoniness \\
& & Canopy & Soil & Litter & \\
\hline Rangeland & Daphenea. sp, Astragalus. sp, Bromus sp & 41.7 & 25.3 & 3.0 & 30 \\
Forest & Quercus persica & $57^{*}$ & 18 & 9 & 18 \\
\hline
\end{tabular}

*based on dominant plant species; ${ }^{* *}$ understory cover. 
Table 3. Descriptive statistical analysis of soil variables in Halashi catchment.

\begin{tabular}{|c|c|c|c|c|c|c|}
\hline Variable & Land Use & Mean & Std Dev & CV (\%) & Min & Max \\
\hline \multirow{3}{*}{ Sand (\%) } & Agriculture & 21.23 & 9.6 & 45.16 & 6.3 & 37.6 \\
\hline & Rangeland & 30.1 & 15.9 & 53.03 & 7.8 & 51.9 \\
\hline & Forest & 21.75 & 3.8 & 17.51 & 14.6 & 28.6 \\
\hline \multirow{3}{*}{ Silt (\%) } & Agriculture & 40.21 & 9.85 & 24.51 & 27.3 & 68.4 \\
\hline & Rangeland & 41.63 & 12.67 & 30.43 & 32.0 & 73.1 \\
\hline & Forest & 37.37 & 3.91 & 10.46 & 31.6 & 42.0 \\
\hline \multirow{3}{*}{ Clay (\%) } & Agriculture & 38.3 & 7.20 & 18.93 & 25.3 & 50.0 \\
\hline & Rangeland & 31.3 & 13.21 & 42.17 & 15.00 & 52.0 \\
\hline & Forest & 40.5 & 4.36 & 10.77 & 32.00 & 46.0 \\
\hline \multirow{3}{*}{$\mathrm{pH}$} & Agriculture & 7.72 & 0.18 & 2.44 & 7.50 & 8.20 \\
\hline & Rangeland & 7.70 & 0.20 & 2.61 & 7.52 & 8.15 \\
\hline & Forest & 7.77 & 0.086 & 1.11 & 7.65 & 7.90 \\
\hline \multirow{3}{*}{$\begin{array}{l}\text { Electrical Conductivity } \\
\qquad(\mathrm{dS} / \mathrm{m})\end{array}$} & Agriculture & 0.85 & 0.24 & 26.55 & 0.40 & 1.30 \\
\hline & Rangeland & 0.66 & 0.19 & 29.75 & 0.32 & 0.90 \\
\hline & Forest & 0.71 & 0.24 & 35.20 & 0.40 & 1.08 \\
\hline \multirow{3}{*}{ Total Nitrogen (\%) } & Agriculture & 0.14 & 0.05 & 37.49 & 0.07 & 0.25 \\
\hline & Rangeland & 0.14 & 0.06 & 47.97 & 0.01 & 0.22 \\
\hline & Forest & 0.18 & 0.03 & 18.22 & 0.14 & 0.22 \\
\hline \multirow{3}{*}{$\begin{array}{l}\text { Available P } \\
(\mathrm{mg} / \mathrm{kg})\end{array}$} & Agriculture & 15.72 & 4.95 & 31.53 & 8.9 & 29.5 \\
\hline & Rangeland & 11.44 & 4.54 & 39.75 & 3.6 & 18.6 \\
\hline & Forest & 11.38 & 2.02 & 17.81 & 8.0 & 15.3 \\
\hline \multirow{3}{*}{$\begin{array}{l}\text { Exchangeable K } \\
(\mathrm{mg} / \mathrm{kg})\end{array}$} & Agriculture & 343.23 & 132.02 & 38.46 & 99 & 580 \\
\hline & Rangeland & 375.50 & 147.05 & 39.16 & 160 & 535 \\
\hline & Forest & 374.50 & 89.78 & 23.97 & 2.9 & 489 \\
\hline \multirow{3}{*}{ Organic Carbon\% } & Agriculture & 1.14 & 0.39 & 29.07 & 0.75 & 2.14 \\
\hline & Rangeland & 1.45 & 0.70 & 48.16 & 0.09 & 2.19 \\
\hline & Forest & 2.13 & 0.19 & 8.99 & 1.75 & 2.36 \\
\hline
\end{tabular}

Table 4. ANOVA analysis of soil texture, $\mathrm{pH}$ and $\mathrm{EC}$ in Halashi catchment ${ }^{*}$.

\begin{tabular}{ccccc}
\hline \multirow{2}{*}{ Soil Variable } & \multicolumn{3}{c}{ Land use } & Pr $>$ F \\
\cline { 2 - 4 } & Agriculture & Rangeland & Forest & 0.0 .0478 \\
\hline Sand (\%) & $21.23^{\mathrm{b}}$ & $30.06^{\mathrm{a}}$ & $21.75^{\mathrm{b}}$ & 0.609 \\
Silt (\%) & $40.21^{\mathrm{a}}$ & $41.63^{\mathrm{a}}$ & $37.37^{\mathrm{a}}$ & 0.0498 \\
Clay (\%) & $38.03^{\mathrm{a}}$ & $31.33^{\mathrm{b}}$ & $40.52^{\mathrm{a}}$ & 0.975 \\
$\mathrm{pH}$ & $7.72^{\mathrm{a}}$ & $7.70^{\mathrm{a}}$ & $7.77^{\mathrm{a}}$ & 0.670 \\
$* * \mathrm{EC}(\mathrm{dS} / \mathrm{m})$ & $0.85^{\mathrm{a}}$ & $0.66^{\mathrm{a}}$ & $0.71^{\mathrm{a}}$ & \\
\hline
\end{tabular}

${ }^{\star}$ Mean with the same letters are not significantly different at $\mathrm{p} \leq 0.05 \%,{ }^{*} \mathrm{EC}=$ electrical conductivity. 


\subsection{Soil NPK and SOC}

SOC: The mean SOC level in the AL, RL and FL was $1.14 \%, 1.45 \%$ and $2.13 \%$, respectively and showing significantly $(\mathrm{p} \leq 0.05)$ different from each other among them (Table 5). It can be seen that the CV and the difference between maximum and minimum in the FL was lower than that of any other lands. The higher level of SOC in the FR and RL are related to relatively higher biomass production compared with AL, enhancing soil. The lower value of SOC in the AL as compared to other lands is associated with conventional tillage practice and burning of crop residues by the local farmers, especially in the hilly lands, increasing $\mathrm{CO}_{2}$ emission.

Field observations showed that crop residues are burnt early autumn into the atmosphere. Improper tillage practices strongly accelerate soil erosion processes by destroying soil organic matter (SOM) and soil structure [14]. Relatively lower level of SOC in the RL is affected by overgrazing. This cause imbalance SOC through defoliation and thereby reducing plant canopy, forage production and litter accumulation as well as different slope gradient [9] [32]. Furthermore, heavy sheep grazing decreased about $16.5 \%$ of SOC [33]. In this area accelerated gully erosion and landslide incidence attribute to $60 \%$ SOC lost. In these areas of Zagros, highest loss in SOC reaches to $306 \mathrm{~kg} \mathrm{ha}^{-1} \mathrm{yr}^{-1}$ by soil erosion in that area [28].

Total N: As shown in Table 5, total $\mathrm{N}$ in the AL, RL and FL is $0.14,0.14$ and $0.18 \mathrm{mg} / \mathrm{kg}$, respectively. Significant lower of total $\mathrm{N}$ in the AL and RL related to crop uptake (without fallow and rotation practices), residue burning and tillage practices as well as improper livestock grazing. This is consistent with other areas, where $\mathrm{N}_{2} \mathrm{O}$ is emitted into the atmosphere, causing global warming although only to a limited extent [3] [34].

Available $P$. The ANOVA showed that $\mathrm{P}$ in the AL was significantly higher than that of the other sites (Table 5). The higher level of $\mathrm{P}$ in the AL may due to over application of $\mathrm{P}_{2} \mathrm{O}_{5}$, while, overgrazing and deforestation factors cause $\mathrm{P}$ deficit in the soil [3] [4].

Over $\mathrm{P}$ input into soil can remain in the soils profile for a longer time compared to $\mathrm{N}$, and consequently can be accumulated in lower drainage systems, rivers and lakes causing eutrophication. This process can be accelerated by conventional tillage practices and erosion compared with no-tillage [35]. This also

Table 5. ANOVA of soil NPK and SOC in Halashi catchment*.

\begin{tabular}{ccccc}
\hline \multirow{2}{*}{ Variable } & \multicolumn{3}{c}{ Land use } & \multirow{2}{*}{ Pr $>$ F } \\
\cline { 2 - 4 } & Agriculture & Rangeland & Forest & \\
\hline SOC (\%) & $1.14^{\mathrm{c}}$ & $1.45^{\mathrm{b}}$ & $2.13^{\mathrm{a}}$ & 0.0001 \\
Total N (mg/kg) & $0.14^{\mathrm{b}}$ & $0.14^{\mathrm{b}}$ & $0.18^{\mathrm{a}}$ & 0.0321 \\
Avail. P (mg/kg) & $15.72^{\mathrm{a}}$ & $11.44^{\mathrm{b}}$ & $11.38^{\mathrm{b}}$ & 0.026 \\
Exc. K (mg/kg) & $342.5^{\mathrm{a}}$ & $375.5^{\mathrm{a}}$ & $374.5^{\mathrm{a}}$ & 0.218 \\
\hline
\end{tabular}

${ }^{*}$ Means with the same letters within rows are not significantly different (at $\mathrm{p} \leq 0.05 \%$ ). 
related to high soil clay content in the study area. The $\mathrm{P}$ level in the run-off sediments increases with decreasing soil particle size [36].

Exchangeable K: The mean exch. $\mathrm{K}$ was $342.5,375.0$ and $374.5 \mathrm{mg} / \mathrm{kg}$ in $\mathrm{AL}$, $\mathrm{RL}$ and FL, respectively. As revealed by ANOVA, soil $\mathrm{K}$ was not significant different from each other among three lands use. There is related to dominants clay minerals, particularly smectie and alkaline $\mathrm{pH}(7-8)$. The main source of $\mathrm{K}$ in the soils is weathering of mica, vermiculite and smectite [37]. The high range between maximum and minimum levels of exchangeable $\mathrm{K}$ in $\mathrm{AL}(580$ and $99 \mathrm{mg} / \mathrm{kg}$ ) is due to different level of $\mathrm{K}$ input and adversely different crops uptake. Overall, sever depletion of SOC and soil NPK are occurred via converting rangeland and forest to rain-fed lands in the Zagros. High CV of K in rangeland (Table 4) is due to slope and relatively higher fragmented vegetation causing its spatial variation due to runoff compared with other sites. The removal of soil $\mathrm{K}$ by runoff is more than that of phosphorus [38]. However, field verification indicated that there are many sources of organic fertilizer in the study area including livestock manure, urban and rural wastewater that can be considered for improving NPK and OC content. It is an ecological sanitation approach to promote closed-loop flows of resources and nutrients from sanitation to agriculture.

\section{Conclusion}

This comparative study revealed that soil nutrient and SOC level in the Halashi catchment significantly are affected by land use practice. The SOC level in AL, $\mathrm{RL}$ and FL was significantly different from each other. The improper agricultural activities, especially tillage and crops residue burning as well as overgrazing cause to total $\mathrm{N}$ change in the AL and RL compared with FL site. In addition, as compared with FL, lower vegetation canopy and litter in the RL promotes soil nutrient and SOC depletion due to overgrazing and converting to rain-fed lands. It is concluded that rangeland was the intermediate site in terms of soil nutrient and SOC stock in the Halashi catchment.

\section{References}

[1] Polyakov, V.O. and Lal, R. (2008) Soil Organic Matter and $\mathrm{CO}_{2}$ Emission as Affected by Water Erosion on Field Run-Off Plots. Geoderma, 143, 216-222. https://doi.org/10.1016/j.geoderma.2007.11.005

[2] Ahmadi, H. (2011) Applied Geomorphology. Vol. 2, Water Erosion. 3rd Edition, Tehran University Press, Tehran, 688 p. (In Persian)

[3] Bechmann, M., Stalnacke, P., Kværno, S., Eggesta, D. and Oygarden, L. (2009) Integrated Tool for Risk Assessment in Agricultural Management of Soil Erosion and Losses of Phosphorus and Nitrogen. Science of the Total Environment, 407, 749-759. https://doi.org/10.1016/j.scitotenv.2008.09.016

[4] Nael, M., Khademi, H.A. and Hajabbasi, M. (2004) Response of Soil Quality Indicators and Their Spatial Variability to Land Degradation in Central Iran. Applied Soil Ecology, 27, 221-232. https://doi.org/10.1016/j.apsoil.2004.05.005

[5] Shahmoradi, A., Gheitori, M., Ahmadi, S. and Tavakoli, A. (2008) Vegetation Assessment and Participatory Development of Techniques for Rehabilitation and Sus- 
tainable Management of Rangelands and Forest Ecosystems of Upper Karkheh River Basin. Iran, Tehran.

[6] Soleimanpour, S.M., Hedayati, B., Soufi, M. and Ahmadi, H. (2015) Determination of Threshold of Effective Factors on Length Expansion of Gullies Using Data Mining Techniques in Mahourmilati Region, Fars Province. Watershed Management Science and Engineering, 9, 47-57. (In Persian)

[7] Munoz-Robles, C., Reid, N., Frazier, P., Tighe, M., Briggs, S.V. and Wilson, B. (2010) Factors Related to Gully Erosion in Woody Encroachment in South Eastern Australia. Catena, 83, 148-157. https://doi.org/10.1016/j.catena.2010.08.002

[8] Heshmati, M., Arifin, A., Shamshuddin, J., Majid, N.M. and Gheitori, M. (2011) Factors Affecting Landslides Occurrence in Agro-Ecological Zones in the Merek Catchment, Iran. Journal of Arid Environment, 75, 1072-1082.

https://doi.org/10.1016/j.jaridenv.2011.06.011

[9] Gheitori, M., Jafary, M., Azarnivand, H., Arzani, H., Javady, S.A. and Heshmati, M. (2012) Contribution of Soil Organic Carbon Levels, Different Grazing and Converted Rangeland on Aggregates Size Distribution in the Rangelands of Kermanshah Province, Iran. African Journal of Agricultural Research, 7, 2622-2631.

[10] Badripour, H., Barani, H., Aghili, S.M. and Abedi Sarvestani, A. (2016) Study the Role of Natural Capitals on Villagers' Dependence on Rangeland (Case Study: HableRud Basin in Iran). Journal of Rangeland Science, 6, 112-121.

[11] Newton, A.C. (2007) Biodiversity and Conservation in Fragmented Forest Landscapes. CABI Press, Wallingford.

[12] Lal, R. (2001) Soil and the Greenhouse Effect. In: Lal, R., Ed., Soil Carbon Sequestration and the Greenhouse Effects, Soil Science Society of America, Madison, 1-8.

[13] Marzaioli, R., Ascoli, R.D., De Pascale, R.A. and Rutigliano, F.A. (2010) Soil Quality in a Mediterranean Area of Southern Italy as Related to Different Land Use Types. Applied Soil Ecology, 44, 205-212. https://doi.org/10.1016/j.apsoil.2009.12.007

[14] Rosa, D.L., Romero, M.A., Pereira, E.D., Heredia, N. and Shahbazi, F. (2009) Soil Specific Agro-Ecological Strategies for Sustainable Land Use; A Case Study by Using Micro LEISDSS in Sevilla Province (Spain). Land Use Policy, 26, 1055-1065. https://doi.org/10.1016/j.landusepol.2009.01.004

[15] Senthilkumar, S., Basso, B., Kravachenko, A.N. and Roberton, G.P. (2009) Cotemporary Evidence of Soil Carbon Loss in the U.S Corn-Belt. Soil Science Society of America Journal, 73, 278-2085. https://doi.org/10.2136/sssaj2009.0044

[16] Moradi, E., Heshmati, G.A. and Bahramian, A.H. (2012) Assessment of Range Health Changes in Zagros Semi-Arid Rangelands, Iran (Case Study: Chalghafa-SemiromIsfahan). Journal of Rangeland Science, 3, 31-43.

[17] Wang, Y., Fu, B., Lu, Y., Song, C. and Luan, Y. (2010) Local-Scale Spatial Variability of Soil Organic Carbon and Its Stock in the Hilly Area of the Loess Plateau, China. Quality Measures, 73, 70-76.

[18] Abera, Y. and Belachew, T. (2011) Effects of Land Use on Soil Organic Carbon and Nitrogen in Soils, Southeastern Ethiopia. Tropical and Subtropical Agroecosystems, 14, 229-235.

[19] Karimi-Bavandpoor, A., Hajihosaini, A. and Shahandi, M. (1999) Geological Map of Kermanshah: 1:100,000 Series: 5458. Geological Survey of Iran Publisher, Tehran.

[20] Soil Survey Staff (2003) Keys to Soil Taxonomy. 9th Edition, United States Department of Agriculture, United States Department of Agriculture Natural Resources Conservation Service, $322 \mathrm{p}$. 
[21] Nelson, R.E. and Sommers, L.E. (1982) Total Carbon, Organic Carbon and Organic Matter. In: Keeney, D.R., Baker, D.E., Miller, R.H., Ellis, R.J. and Rhoades., J.D., Eds., Methods of Soil Analysis, Part 2, Chemical and Microbiological Properties, American Society of Agronomy, Soil Science, Madison, 539-580.

[22] Bremner, J.M. and Mulvaney, C.S. (1982) Nitrogen-Total. In: Page, A.L., Keeney, D.R., Baker, D.E., Miller, R.H, Ellis, R.J. and Rhoades, J.D., Eds., Methods of Soil Analysis, Part 2, Chemical and Microbiological Properties, American Society of Agronomy, Soil Science, Madison, 595-622.

[23] Van-Reeuwijke, L.P. and Vente, J. (1993) Procedure for Soil Analysis. International Soil Reference and Information Center.

[24] Knudsen, D., Peterson, G.A. and Preatt, P.E. (1982) Lithium, Sodium and Potassium. In: Page, A.L., Keeney, D.R., Baker, D.E., Miller, R.H., Ellis, R.J. and Rhoades, J.D., Eds., Methods of Soil Analysis, Part 2, Chemical and Microbiological Properties, American Society of Agronomy, Soil Science, Madison, 225-247.

[25] Wani, P.P. and Sudi, R. (2006) Gully Control in SAT Watershed. International Crops Research Institute for the Semi-Arid Tropics, SAT, Vol. 2, Issue 1.

[26] Parkner, T.M., Page, M., Marden, N. and Marutani, T. (2007) Gully Systems under Undisturbed Indigenous Forest, East Coast Region. Geomorphology, 84, 241-253. https://doi.org/10.1016/j.geomorph.2006.01.042

[27] Morgan, R.P.C. (2005) Soil Erosion and Conservation. Blackwell Publisher, Oxford, London.

[28] Heshmati, M., Arifin, A., Shamshuddin, J. and Majid, N.M. (2012) Predicting N, P, $\mathrm{K}$ and Organic Carbon Depletion in Soils using MPSIAC Model at the Merek Catchment, Iran. Geoderma, 175-176, 64-77. https://doi.org/10.1016/i.geoderma.2011.12.028

[29] Frydman, S.T., Alesnick, M., Geffen, S. and Shvarzman, A. (2007) Landslides and Residual Strength in Marls Profiles in Israel. Engineering Geology, 89, 36-46. https://doi.org/10.1016/j.enggeo.2006.09.009

[30] Krenz, J., Lee, B. and Owens, P. (2000) Swelling Clays and Septic Systems: High Water Tables and Septic System Perimeter Drains. Department of Agriculture (USDA). http://www.ces.purdue.edu/extmedia

[31] Gheitori, M. and Tavakoli, A. (2008) Vegetation Cover of Natural Resources in the Merek Site. CGIAR Challenge Program on Water and Food and Agriculture and Natural Resources Research Center of Kermanshah, Iran.

[32] Mondal, A., Khare, K., Kundu, S., Mondal, S., Mukherjee, S. and Mukhopadhyay, A. (2017) Spatial Soil Organic Carbon (SOC) Prediction by Regression Kriging using Remote Sensing Data. The Egyptian Journal of Remote Sensing and Space Sciences, 20, 61-70. https://doi.org/10.1016/j.ejrs.2016.06.004

[33] Li, G.L. and Pang, X.M. (2010) Effect of Land-Use Conversion on C and N Distribution in Aggregate Fractions of Soils in the Southern Loess Plateau, China. Land Use Policy, 27, 706-712. https://doi.org/10.1016/j.landusepol.2009.09.011

[34] Dala, R.C., Wang, W., Robertson, G.P., Parton, W.J., Myer, C. and Raisin, R.J. (2003) Nitrous Oxide Emission from Australian Agricultural Lands and Mitigation Options. Soil Research, 41, 165-195. https://doi.org/10.1071/SR02064

[35] Mengel, D.K. and Kirkby, E.A. (2001) Principles of Plant Nutrition. Kluwer Academic Publisher, Dordrecht. https://doi.org/10.1007/978-94-010-1009-2

[36] Barbosa, F.T., Bertol, I., Luciano, R.V. and Gonzalez, A.P. (2009) Phosphorus Losses in Water and Sediments in Runoff of the Water Erosion in Oat and Vetch Crops 
Seed in Contour and Downhill. Soil \& Tillage Research, 106, 22-28.

https://doi.org/10.1016/j.still.2009.09.004

[37] Borchardt, G. (1989) Smectites. In: Bighman, J.M., Dixon, J.B., Milford, M.H., Roth, C.B. and Weed, S.B., Eds., Minerals in Soil Environments, American Society of Agronomy, Soil Science, Madison, 728-767.

[38] Bertol, I., Engel, F.L., Mafra, A.L., Bertol, O.J. and Ritter, S.R. (2007) Phosphorus, Potassium and Organic Carbon Concentrations in Run-Off Water and Sediments under Different Soil Tillage Systems during Soybean Growth. Soil \& Tillage Research, 94, 142-150. https://doi.org/10.1016/j.still.2006.07.008 